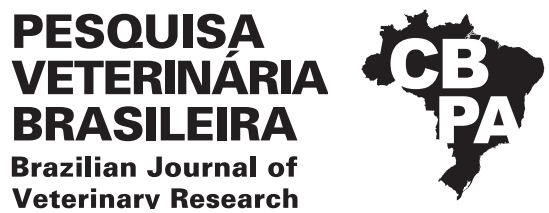

Pesq. Vet. Bras. 41:e06640, 2021

DOI: $10.1590 / 1678-5150-P V B-6640$

Original Article

Small Animal Diseases

ISSN 0100-736X (Print)

(cc) BY-NC

ISSN 1678-5150 (Online)

\title{
Cross-sectional survey for canine leptospirosis in an Atlantic Rainforest area of the semiarid of Paraíba state, Northeastern Brazil ${ }^{1}$
}

\author{
Maria G.S. Bernardino ${ }^{2}$, Diego F. Costa ${ }^{2}$, Denise B. Nogueira², Maria L.C.R. Silva ${ }^{2}$, \\ Edijanio G. Silva ${ }^{2}$, Artur N. Carreiro ${ }^{2}$, Clebert J. Alves ${ }^{2}$ (D) and Sérgio S. Azevedo ${ }^{2 *}$ (D)
}

\begin{abstract}
Bernardino M.G.S., Costa D.F., Nogueira D.B., Silva M.L.C.R., Silva E.G., Carreiro A.N., Alves C.J. \& Azevedo S.S. 2021. Cross-sectional survey for canine leptospirosis in an Atlantic Rainforest area of the semiarid of Paraíba state, Northeastern Brazil. Pesquisa Veterinária Brasileira 41:e06640, 2021. Unidade Acadêmica de Medicina Veterinária, Centro de Saúde e Tecnologia Rural, Universidade Federal de Campina Grande, Av. Universitária s/n, Cx. Postal 61, Santa Cecília, Patos, PB 58700-970, Brazil. E-mail: sergio@vps.fmvz.usp.br

Leptospirosis is a worldwide zoonosis caused by the bacteria Leptospira spp. that affects humans, domestic and wild animals. The present work aimed to conduct a cross-sectional survey for leptospirosis in the canine population of the Brejo Paraibano microregion, semiarid of Northeastern Brazil. From May to October 2017, blood samples from 414 dogs were collected in the counties of Alagoa Grande $(\mathrm{n}=100)$, Areia $(\mathrm{n}=79)$, Bananeiras $(\mathrm{n}=72)$, Alagoa Nova $(n=73)$, Serrraria $(n=25)$, Pilões $(n=25)$, Borborema $(n=20)$ and Matinhas $(n=20)$. The tutors of the sampled dogs answered an epidemiological questionnaire, obtaining information about the animals, owner, residence and breeding of the dogs. Subsequently, the serum samples were subjected to the microscopic agglutination test (MAT), using a collection of 23 serovar pathogenic antigens and using the 1:50 dilution as the cutoff point. Of the 414 dogs analyzed 52 were seroreactive, resulting in an apparent prevalence of $12.6 \%$ and a real prevalence of $12.2 \%$. Seroreactive dogs were found in the eight counties. Dogs were reactive for the serogroups Icterohaemorrhagiae (76.9\%), Autumnalis (13.55\%), Pomona (3.8\%), Grippotyphosa (3.8\%) and Serjoe (1.9\%) Antibody titers ranged from 50 to 800 . The statistical analysis (robust Poisson regression) detected six factors associated with seropositivity, including the rainy season (prevalence ratio; $\mathrm{PR}=1.94, P=0.013)$, male dogs ( $\mathrm{PR}=2.10, P=0.005)$, animals with age greater than five years ( $P R=4.21, P=0.012$ ), consumption of untreated water ( $P R=1.87, P=0.043$ ), free access of dogs to street $(\mathrm{PR}=2.15, P=0.011$ ) and contact with wildlife ( $\mathrm{PR}=3.54, P=0.050)$. The serogroup Icterohaemorrhagiae has a high zoonotic potential and was the most frequent in seropositive animals. The high real prevalence of Leptospira spp. in a transmission region of the semiarid region of Paraíba and the occurrence of seroreactive animals in all the counties suggest wide distribution of the infection and reinforce the need for preventive measures to avoid infection in pets and, consequently, to humans. The analysis of factors associated with the prevalence suggest greater manegment cares with the dogs.
\end{abstract}

INDEX TERMS: Cross-sectional survey, canine, leptospirosis, Atlantic Rainforest, Brazil, epidemiology, zoonosis, pets, dogs, One Health.

RESUMO.- [Estudo transversal para leptospirose canina em área de Mata Atlântica do semiárido da Paraíba, Nordeste do Brasil.] A leptospirose é uma zoonose mundial causada pela bactéria Leptospira spp. que afeta seres humanos,

\footnotetext{
${ }^{1}$ Received on March 17, 2020.

Accepted for publication on March 9, 2021.

${ }^{2}$ Graduate Program in Animal Science and Health, Centro de Tecnologia de Saúde Tecnologia Rural (CSTR), Universidade Federal de Campina Grande (UFCG), Av. Universitária s/n, Bairro Santa Cecília, Patos, PB 58708-110, Brazil. *Corresponding author: sergio@vps.fmvz.usp.br
}

animais domésticos e selvagens. 0 presente trabalho teve como objetivo realizar um estudo transversal de leptospirose na população canina da microrregião Brejo Paraibano, semiárido do Nordeste do Brasil. No período de maio a outubro de 2017, amostras de sangue de 414 cães foram coletadas nas cidades de Alagoa Grande $(\mathrm{n}=100)$, Areia $(\mathrm{n}=79)$, Bananeiras $(n=72)$, Alagoa Nova $(n=73)$, Serraria $(n=25)$, Pilões $(n=25)$, Borborema $(n=20)$ e Matinhas $(n=20)$. Os tutores dos cães amostrados responderam a um questionário epidemiológico, sendo obtidas informações sobre os animais, proprietário, 
residência e criação dos cães. Posteriormente as amostras de soro foram submetidas à prova de soroaglutinação microscópica (SAM), utilizando-se uma coleção de 23 sorovares antígenos patogênicos e adotando como ponto de corte a diluição 1:50. Dos 414 cães analisados 52 foram sorreativos, resultando em uma prevalência aparente de $12.6 \%$ e uma prevalência real de 12,2\%. Cães sororreativos foram encontrados nos oito municípios. Os cães foram reativos para o sorogrupo Icterohaemorrhagiae (76,9\%), Autumnalis (13,55\%), Pomona (3,8\%), Grippotyphosa (3,8\%) and Serjoe $(1,9 \%)$ Os títulos de anticorpos variaram de 50 a 800 . A análise estatística (regressão de Poisson robusta) detectou seis fatores associados à soropositividade, incluindo o período chuvoso (razão de prevalência - $\mathrm{RP}=1,94 ; P=0,013)$, cães machos $(\mathrm{RP}=2,10$; $P=0,005)$, animais com idade maior que cinco anos $(R P=4,21$; $P=0,012)$, consumo de água não tratada ( $R P=1,87 ; P=0,043)$, cães com livre acesso à rua $(\mathrm{RP}=2,15 ; P=0,011)$ e contato com animais silvestres $(\mathrm{RP}=3,54 ; P=0,050)$. Os resultados desse estudo indicaram que há a exposição por Leptospira spp. em cães da microrregião do Brejo paraibano. 0 sorogrupo Icterohaemorrhagiae possui alto potencial zoonótico e foi o mais frequente nos animais soropositivos. A alta prevalência real de Leptospira spp. em uma região de transmissão da região semiárida da Paraíba e a ocorrência de animais sororreativos em todos os municípios sugerem uma ampla distribuição da infecção e reforçam a necessidade de medidas preventivas para evitar a infecção em animais de estimação e, consequentemente, em seres humanos. A análise dos fatores associados à prevalência sugere maior cuidado com os cães.

TERMOS DE INDEXAÇÃO: Estudo transversal, leptospirose, caninos, Mata Atlântica, Brasil, epidemiologia, zoonose, animais de estimação, Saúde Única.

\section{INTRODUCTION}

Leptospirosis is a zoonotic disease with worldwide distribution and increasing prevalence (Lane \& Dore 2016) caused by pathogenic bacteria belonging to the genus Leptospira, which can affect humans, domestic and wild animals (Ellis 2015). In humans, Brazil has an endemic situation, with an annual average of three thousand cases confirmed (SINAN 2017), and in this context, humans act as accidental hosts and when infected they can develop the severe form of the disease (Haake \& Levett 2015).

In the urban environment, the main reservoirs of the disease are synanthropic animals (Scialfa et al. 2010, Benacer et al. 2013). In addition, several domestic and wild species can act as important reservoirs in the epidemiological cycle (Vieira et al. 2016, Miotto et al. 2018a, Zarantonelli et al. 2018). The indirect way is the main route of transmission of the agent, through contact with water or soil contaminated with the urine of infected animals (Haake \& Levett 2015).

From the One Health point of view, human health is linked to animal and environmental health, as well as to the adoption of effective public policies for the prevention and control of diseases at the local, regional, national and global levels (OIE 2019). Taking this as an assumption, surveys with dogs can provide important information for various problems that affect human health, as these animals have close contact with humans and act as sentinels for various diseases. In addition, dogs can host and amplify various infectious agents of great importance in public health, including leptospires, and when infected they can develop the subclinical condition and act as carriers (Oliveira et al. 2012).

The prevalence of the disease is influenced by several factors, including geographic distribution and socioeconomic factors (Baquero \& Machado 2018), and in this context the conduction of epidemiological surveys in different locations is important. Some surveys with dogs have been carried out in the state of Paraíba (Alves et al. 2004, Batista et al. 2004, Azevedo et al. 2011, Silva et al. 2017b, Brasil et al. 2018, Fernandes et al. 2018a, 2018b), however, there are still no surveys that indicate the epidemiological situation of canine leptospirosis in the Brejo paraibano microregion, which can be considered a important transmission area, as this region presents specific characteristics that may influence the occurrence of this disease, including the presence of remnants of the Atlantic Rainforest (Porto et al. 2004) and high rainfall (AESA 2019). According to data from the Ministry of Health, 325 cases of human leptospirosis from 2000 to 2018 were confirmed in the state of Paraíba (SINAN 2017), which reinforces the need to carry out epidemiological surveys in the region. Therefore, this work aimed to conduct a crosssectional study for leptospirosis in the canine population of the Brejo Paraibano microregion, semiarid of Northeastern Brazil.

\section{MATERIALS AND METHODS}

The present study was approved by the Research Ethics Committee of the "Centro de Tecnologia de Saúde Tecnologia Rural" (CSTR) of the "Universidade Federal de Campina Grande" (UFCG), under protocol no. 025/2017.

Study area and sampling. This study was conducted on dogs living in the urban area of the Brejo Paraibano microregion, in the state of Paraíba, Northeastern Brazil, which consists of eight municipalities, namely: Alagoa Grande, Alagoa Nova, Areia, Bananeiras, Borborema, Matinhas, Pilões and Serraria. Its territorial area is $840,452 \mathrm{~km}^{2}$, with a population of 116,488 inhabitants (IBGE 2010).

In order to define the minimum number of animals to be sampled the formula for simple random sampling was used (Thrusfield 2007), considering the following parameters: expected prevalence of $50 \%$ (sample maximization), confidence level of $95 \%(\mathrm{z}=1.96)$ and statistical error of $5 \%$. With these parameters a minimum sample size of 384 dogs was required, but we provided a sample of 414 dogs older than three months of age, of both sexes (193 females and 221 males) and different breeds, without leptospirosis vaccination history in the last 12 months. The minimum number of dogs to be sampled in each municipality of the microregion was defined proportionally according to the number of inhabitants (Table 1).

Sample collection. The fieldwork was conducted by a trained team through home visits to the residents of the microregion. The dogs' owners were given explanations about the objectives of the study and, after agreeing to participate, signed a free and informed consent statement. The collection of the samples was carried out from May and October 2017, comprising two periods of different pluviometric indexes: rainy (May to July) and dry (August to October). From each animal a blood sample was collected, and after removal of the coagulum the serum was transferred to $1.5-\mathrm{mL}$ microtubes and stored at $-20^{\circ} \mathrm{C}$ until the serological tests.

A questionnaire was applied to the owners to obtain data to be used in the analysis of factors associated with seroprevalence. The variables and respective categories considered in the questionnaire were: 
a) Information about the season and dogs: season (dry, rainy), sex (female, male), age (up to 1 year, 1-5 years, over 5 years), and breed (without defined breed, with defined breed);

b) Information about owner and residence: educational level (illiterate/incomplete primary education, completed elementary school), disposal of garbage (public collection, vacant lots/on the streets), presence of rodents (no, yes), type of water for consumption (treated, untreated), and yard (no/cement, soil/soil-cement);

c) Characteristics of animal husbandry: condition of housing (domiciled/semi-domiciled, free access to streets), dog food (commercial, commercial + homemade), ectoparasite control (yes, no), deworming (yes, no), veterinary assistance (yes, no), animal with access to vacant lots (yes, no), contact with small ruminants (yes, no), contact with cattle (yes, no), contact with horses (yes, no), and contact with wildlife (yes, no).

Serological test. For anti-Leptospira sp. antibody detection the microscopic agglutination test (MAT) (OIE 2018) was used. The antigens used were strains of Leptospira interrogans serovars Copenhageni, Bratislava, Canicola, Grippotyphosa, Hardjoprajitno, Pomona, Pomona Fromm, Pyrogenes, Icterohaemorrhagiae, Hebdomadis and Wolffi; L. borgpetersenii serovars Autumnalis, Javanica, Tarassovi, Mini and Ballum; L. santarosai serovars Guaricura, Canalzone and Shermani; L. kirschneri serovar Cynopteri; L. noguchii serovars Panama and Lousiana; $L$. weilli serovar Celledoni. Sera were screened at the 1:50 dilution, and those with $50 \%$ or more of agglutination were titrated by examining a series of geometric dilutions of ratio two. The serum titer was defined as the reciprocal of the highest dilution that showed positive result, and the cutoff point adopted was titer $\geq 50$. The reagent serogroup in each animal was defined by the serovar that had the highest titer.

Statistical analysis. Apparent and real prevalences were calculated according to Noordhuizen et al. (1997). Apparent prevalence was obtained by the ratio between the number of seroreactive animals and the total number of animals. Real prevalence value was estimated by the adjustment of apparent prevalence for the sensitivity (82\%) and specificity (97\%) of the MAT (Cumberland et al. 1999):

$$
\mathrm{RP}=\frac{(\mathrm{AP}+\mathrm{SPE}-1)}{(\mathrm{SEN}+\mathrm{SPE}-1)}
$$

Where: $\mathrm{RT}=$ real prevalence, $\mathrm{AP}=$ apparent prevalence, $\mathrm{SPE}=$ specificity, and SEN = sensitivity.
The information obtained with the epidemiological questionnaires and serological tests were stored in a database created with the Microsoft Excel software. To conduct the analysis of factors associated with seropositivity, univariable analysis was initially performed, in which each independent variable underwent an association analysis in relation to the dependent variable (seropositivity in serological tests). Variables with $P$-value $\leq 0.2$ in the Chi-square test (Zar 1999) were selected for multivariable analysis using robust Poisson regression. Collinearity between independent variables was verified by a correlation analysis; for those variables with a strong collinearity (correlation coefficient $>0.9$ ), one of the two variables was excluded from the multiple analysis according to the biological plausibility (Dohoo et al. 1996). To assess how well the model fits the Person Chi-square was used, and the significance of the model was verified with Omnibus test. The significance level adopted in the multiple analysis was 5\%, and the software used was SPSS for Windows version 20.0.

\section{RESULTS}

Of the 414 dogs analyzed 52 were seroreactive, resulting in an apparent prevalence of $12.6 \%$ and a real prevalence of $12.2 \%$. Seroreactive dogs were found in the eight counties (Table 1 and Fig.1), with the highest prevalence obtained in the county of Serraria (28\%), followed by Areia (20.2\%), Pilões (20\%), Matinhas (15\%), Borborema (10\%), Alagoa Nova (9.6\%), Alagoa Grande (7\%) and Bananeiras (6.9\%).

Dogs were reactive for the serogroups Icterohaemorrhagiae (76.9\%), Autumnalis (13.55\%), Pomona (3.8\%), Grippotyphosa (3.8\%) and Serjoe (1.9\%) (Table 2). Antibody titers ranged from 50 to 800 according to the following distribution: five (9.6\%) dogs showed titer 50, $11(21.2 \%)$ titer $100,18(34.6 \%)$ titer 200 , nine (17.3\%) titer 400 and nine (17.3\%) titer 800 .

Variables selected in the univariable analysis $(P<0.20)$ were season $(P=0.003)$, sex $(P=0.119)$, age $(P<0.001)$, breed $(P=0.018)$, owner's educational level $(P=0.005)$, disposal of garbage $(P<0.001)$, presence of rodents $(P=0.165)$, type of water for consumption $(P<0.001)$, characteristics of the yard $(P=0.011)$, condition of housing $(P<0.001)$, dog food $(P=0.008)$, ectoparasite control $(P=0.161)$, veterinary assistance $(P=0.118)$, access to vacant lots $(P<0.001)$, contact with cattle

Table 1. Numbers of inhabitants, minimum number of dogs to be sampled, sampled dogs, positive animals in each municipality and serogroups detected in the Brejo Paraibano microregion

\begin{tabular}{|c|c|c|c|c|c|}
\hline 'Municipality & Inhabitants* & $\begin{array}{l}\text { Minimum number of } \\
\text { dogs to be sampled }\end{array}$ & Sampled dogs & Positive dogs (\%) & Serogroups detected \\
\hline Areia & 23,829 & 78 & 79 & $16(20.2)$ & $\begin{array}{c}\text { Icterohaemorrhagiae, } \\
\text { Autumnalis, Serjoe }\end{array}$ \\
\hline Bananeiras & 21,851 & 72 & 72 & $5(6.9)$ & Icterohaemorrhagiae \\
\hline Alagoa Nova & 19,681 & 65 & 73 & $7(9.6)$ & $\begin{array}{l}\text { Icterohaemorrhagiae, } \\
\text { Autumnalis, Pomona }\end{array}$ \\
\hline Pilões & 6,978 & 23 & 25 & $5(20)$ & $\begin{array}{c}\text { Icterohaemorrhagiae, } \\
\text { Grippotyphosa, } \\
\text { Pomona }\end{array}$ \\
\hline Borborema & 5,111 & 17 & 20 & $2(10)$ & Autumnalis \\
\hline
\end{tabular}


$(P=0.001)$, contact with horses $(P=0.021)$ and contact with wildlife $(P<0.001)$ (Table 3$)$.

In the robust Poisson regression analysis, six factors associated with seroprevalence were confirmed (Table 4), including the rainy season (prevalence ratio - $P R=1.94, P=0.013$ ), male dogs ( $\mathrm{PR}=2.10, P=0.005)$, animals with age greater than five years $(\mathrm{PR}=4.21, P=0.012)$, consumption of untreated water $(\mathrm{PR}=1.87$, $P=0.043)$, free access of dogs to street $(\mathrm{PR}=2.15, P=0.011)$ and contact with wildlife ( $\mathrm{PR}=3.54, P=0.050$ ). The model presented good fit (Pearson Chi-square: value $=312.78$, degrees of freedom $-\mathrm{df}=397$, value $/ \mathrm{df}=0.788$ ) and statistical significance (Omnibus test: likelihood ratio Chi-square $=73.27, \mathrm{df}=16, P<0.001$ ).

\section{DISCUSSION}

The real prevalence of dogs seroreactive for Leptospira sp. obtained in this survey can be considered high given the importance of infection from the One Health point of view, because in addition to the impacts on animal and public health, the infection has a strong environmental component in its epidemiology. It is noteworthy that all counties in the region had seroreactive animals, with prevalence rates ranging from $7 \%$ to $28 \%$. These results alert to the intensification of preventive measures that minimize the risk of exposure of animals and humans to the agent, especially in the case of a region that has favorable environmental conditions for the

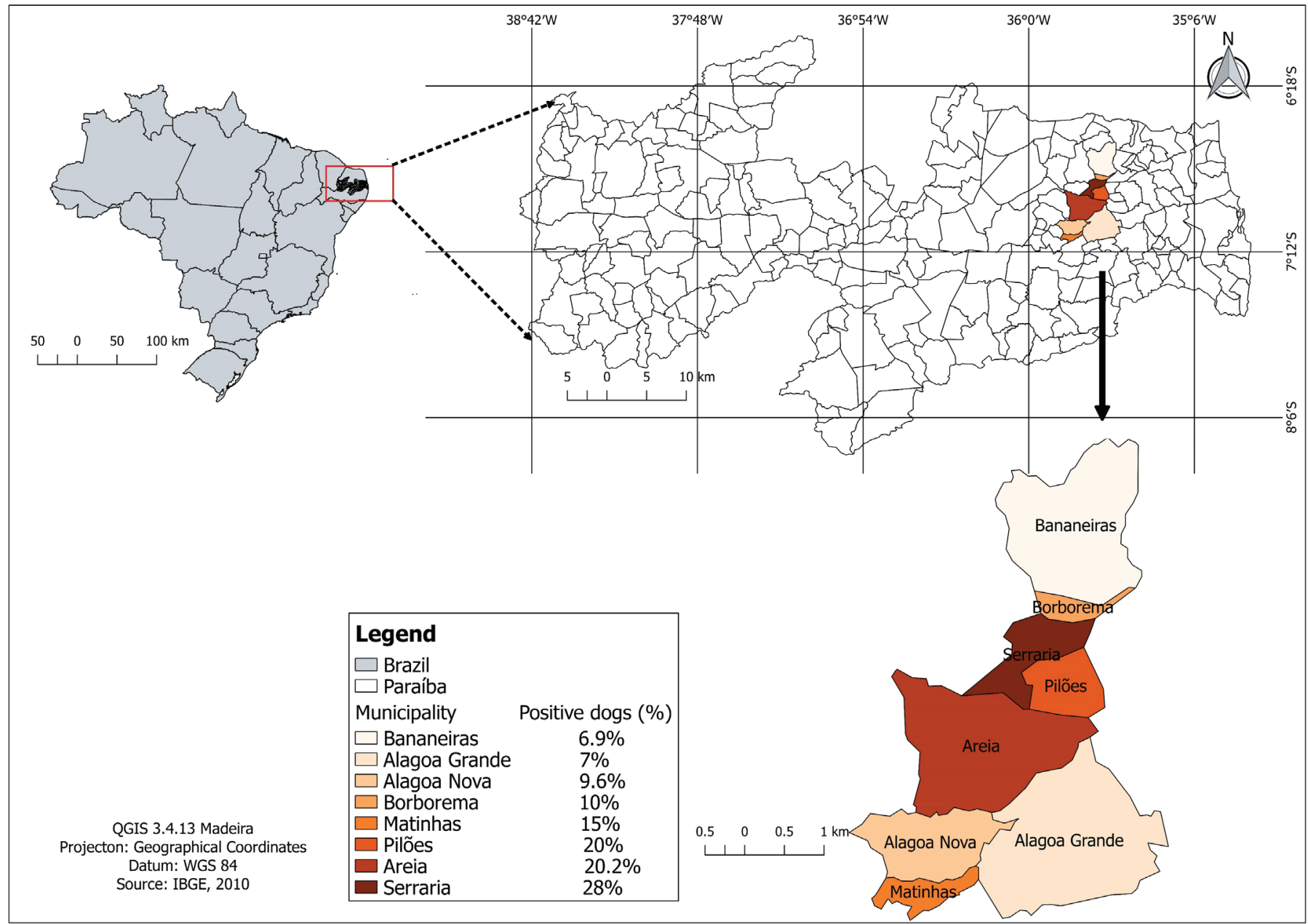

Fig.1. Geographic representation of the municipalities in the Brejo Paraibano microrregion and respective seropositivity to Leptospira sp. in dog population.

Table 2. Frequency of anti-Leptospira antibodies according to serogroup detected in 52 dogs in the Brejo Paraibano microregion, from May to October 2017

\begin{tabular}{|c|c|c|c|c|c|c|}
\hline \multirow{2}{*}{ Serogroup } & \multicolumn{5}{|c|}{ Titration } & \multirow{2}{*}{ Total (\%) } \\
\hline & 50 & 100 & 200 & 400 & 800 & \\
\hline Autumnalis & 2 & 1 & 3 & - & 1 & 7 (13.5) \\
\hline Grippotyphosa & - & - & 1 & - & 1 & $2(3.8)$ \\
\hline Serjoe & - & - & 1 & - & - & $1(1.9)$ \\
\hline
\end{tabular}


spread of leptospires. It is worthy mentioning that titration equal to or greater than 800 indicates an acute infection in dogs and on this clinical condition they can eliminate live leptospires in the urine (Miotto et al. 2018b), so that this finding shows the high risk of infection for humans due to the close relationship with their pets.

The most prevalent serogroup was Icterohaemorrhagiae, which is implicated as a cause of acute and severe disease in dogs (Freire et al. 2008), as well as one of the most frequent and pathogenic for humans (Romero et al. 2003). This data is relevant because infected dogs eliminate live leptospires through urine (Freitas et al. 2004, Miotto et al. 2018b), becoming important sources of infection for humans due to their close relationship. The predominance of the serogroup Icterohaemorrhagiae is not a common finding when compared to studies carried out in recent years in other regions of Brazil. In the Southern region, the most common serogroups were Canicola and Autumnalis (Morikawa et al. 2015, Oliveira et al. 2016, Hafemann et al. 2018, Pinto-Ferreira et al. 2019), in Minas Gerais the serogroups Autumnalis, Tarassovi, Canicola and Grippotyphosa (Castro et al. 2015), in Pará, Canicola, Semaranga and Icterohaemorrhagiae (Paz et al. 2015), and in Piauí, the serogroups Canicola, Autumnalis and Australis were the most frequent (Silva et al. 2017a).

On the other hand, the higher frequency of the serogroup Icterohaemorrhagiae was also recently reported in dogs

Table 3. Univariable analysis on the factors associated with seroprevalence for leptospirosis among dogs in the Brejo Paraibano microregion

\begin{tabular}{|c|c|c|c|c|}
\hline Variable & Categories & Total no. of dogs & Positive dogs (\%) & $P$-value \\
\hline \multirow[t]{2}{*}{ Season } & Dry & 223 & $18(8.1)$ & $0.003^{*}$ \\
\hline & Rainy & 191 & $34(17.8)$ & \\
\hline \multirow[t]{2}{*}{ Sex } & Female & 193 & $19(9.8)$ & 0.119* \\
\hline & Male & 221 & $33(14.9)$ & \\
\hline \multirow[t]{3}{*}{ Age } & Up to 1 year & 89 & $3(3.4)$ & $<0.001^{*}$ \\
\hline & $1-5$ years & 200 & $20(10.0)$ & \\
\hline & Over 5 years & 125 & $29(23.2)$ & \\
\hline \multirow[t]{2}{*}{ Breed } & With defined breed & 72 & $3(4.2)$ & $0.018^{*}$ \\
\hline & Without defined breed & 342 & $49(14.3)$ & \\
\hline \multirow[t]{2}{*}{ Owner's educational level } & Illiterate/incomplete primary education & 124 & $7(5.6)$ & $0.005^{*}$ \\
\hline & Completed elementary school & 290 & $45(15.5)$ & \\
\hline \multirow[t]{2}{*}{ Disposal of garbage } & Public collection & 395 & $44(11.1)$ & $<0.001^{*}$ \\
\hline & Vacant lots/on the streets & 19 & $8(42.1)$ & \\
\hline \multirow[t]{2}{*}{ Presence of rodents } & No & 104 & $9(8.7)$ & $0.165^{*}$ \\
\hline & Yes & 310 & $43(13.9)$ & \\
\hline \multirow{2}{*}{ Type of water for consumption } & Treated water & 218 & $14(6.4)$ & $<0.001^{*}$ \\
\hline & Untreated water & 196 & $38(19.4)$ & \\
\hline \multirow[t]{2}{*}{ Characteristics of the yard } & No/cement & 127 & $8(6.3)$ & $0.011^{*}$ \\
\hline & Soil/ soil-cement & 287 & $44(15.3)$ & \\
\hline \multirow[t]{2}{*}{ Condition of housing } & Domiciled/Semi-domiciled & 332 & $29(8.7)$ & $<0.001^{*}$ \\
\hline & Free access to streets & 82 & $23(28.0)$ & \\
\hline \multirow[t]{2}{*}{ Dog food } & Commercial & 190 & $15(7.9)$ & $0.008^{*}$ \\
\hline & Commercial + homemade & 224 & $37(16.5)$ & \\
\hline \multirow[t]{2}{*}{ Ectoparasite control } & Yes & 48 & $3(6.2)$ & $0.161^{*}$ \\
\hline & No & 366 & $49(13.4)$ & \\
\hline \multirow[t]{2}{*}{ Deworming } & Yes & 8 & $2(25.0)$ & 0.284 \\
\hline & No & 406 & $50(12.3)$ & \\
\hline \multirow[t]{2}{*}{ Veterinary assistance } & Yes & 41 & $2(4.9)$ & $0.118^{*}$ \\
\hline & No & 373 & $50(13.4)$ & \\
\hline \multirow[t]{2}{*}{ Animal with access to vacant lots } & No & 177 & $8(4.5)$ & $<0.001^{*}$ \\
\hline & Yes & 237 & $44(18.6)$ & \\
\hline \multirow[t]{2}{*}{ Contact with small ruminants } & No & 386 & $47(12.2)$ & 0.381 \\
\hline & Yes & 28 & $5(17.9)$ & \\
\hline \multirow[t]{2}{*}{ Contact with cattle } & No & 403 & 47 (11.7) & $0.001^{*}$ \\
\hline & Yes & 11 & $5(45.5)$ & \\
\hline \multirow[t]{2}{*}{ Contact with horses } & No & 398 & 47 (11.8) & $0.021^{*}$ \\
\hline & Yes & 16 & $5(31.2)$ & \\
\hline \multirow[t]{2}{*}{ Contact with wildlife } & No & 139 & $3(2.2)$ & $<0.001^{*}$ \\
\hline & Yes & 275 & $49(17.8)$ & \\
\hline
\end{tabular}


Table 4. Factors associated with seroprevalence for leptospirosis among dogs in the Brejo Paraibano microregion, determined using robust Poisson regression analysis

\begin{tabular}{|c|c|c|c|c|c|c|}
\hline Variable category & Coefficient estimates & Standard error & Wald Chi-square & Prevalence ratio (PR) & $95 \% \mathrm{CI}$ & $P$-value \\
\hline Untreated water for consumption & 0.625 & 0.309 & 4.091 & 1.87 & $1.02 ; 3.43$ & 0.043 \\
\hline Rainy season & 0.660 & 0.2657 & 6.171 & 1.94 & $1.15 ; 3.26$ & 0.013 \\
\hline Male dog & 0.743 & 0.2655 & 7.835 & 2.10 & $1.25 ; 3.54$ & 0.005 \\
\hline Free access to streets & 0.767 & 0.3007 & 6.509 & 2.15 & $1.20 ; 3.89$ & 0.011 \\
\hline Contact with wildlife & 1,263 & 0.658 & 3.683 & 3.54 & $1.00 ; 12.85$ & 0.050 \\
\hline Age over 5 years & 1.438 & 0.5717 & 6.323 & 4.21 & $1.37 ; 12.91$ & 0.012 \\
\hline
\end{tabular}

Goodness of fit: Pearson Chi-square value $=312.78$, degrees of freedom $=397$, value $/ \mathrm{df}=0.788 ; \mathrm{CI}=$ confidence interval.

from other regions of the state of Paraíba, with a frequency of $47 \%$ in dogs residing in large urban centers (Fernandes et al. 2018a) and 43\% in dogs from the Sertão of Paraíba (Fernandes et al. 2018b). These data show that the serogroup Icterohaemorrhagiae is being maintained in dogs from the state of Paraíba and reinforces the importance of rodent control in the urban environment, as it is known that the main reservoir of this serogroup in urban environments is the rat (Rattus novergicus), which is resistant to clinical disease and hosts bacteria in the kidneys, eliminating them through urine intermittently for long periods (Brasil 2017). In addition, the fact that the Brejo paraibano has a large forest area indicates the possible participation of wild hosts that maintain serogroup Icterohaemorrhagiae in the epidemiological cycle of the region.

The Autumnalis serogroup was the second most prevalent, and although it is considered uncommon in dogs, in recentyears there has been an increase in seropositivity reports (Lemos et al. 2010, Castro et al. 2011, 2015). It is worth mentioning that among domestic species, this serogroup is more frequently reported as predominant in sheep (Alves et al. 2004, 2012, Higino et al. 2010, Barbante et al. 2014) and goat (Araújo Neto et al. 2010, Higino et al. 2012, 2013, Pimenta et al. 2019). Therefore, it is likely that sheep and goat may be acting as reservoirs for this serogroup, thus contaminating the environment and other species, including dogs. Seropositivity for serogroup Autumnalis is also of concern, since vaccines commercially available for dogs do not include bacteria from that serogroup, so that animals can be susceptible to infection even when vaccinated.

Serogroups Pomona, Grippotyphosa and Serjoe were also detected in the presente survey. Pomona is commonly found in pigs, being adapted to this species (Miraglia et al. 2015), wild animals tend to be reservoirs of the Grippotyphosa serogroup (Allen et al. 2014, Pedersen et al. 2018) and cattle are often associated with the Serjoe (Pimenta et al. 2019). Therefore, it is possible that other animal species act as important reservoirs in the epidemiological cycle of leptospirosis in the region.

Cross-sectional studies are one of the most frequently designed observational studies in animal leptospirosis as well as in veterinary epidemiology, likely because they are rapid, inexpensive and of moderate difficulty, and the odds ratio (OR) is the most usual association measure estimated. However, when the binary outcome is common, usually with a prevalence greater than $10 \%$, the prevalence ratio (PR) can be overestimated by the OR when the PR is greater than one or underestimated when the PR is less than one (Martinez et al. 2017). In this survey a robust Poisson regression was used to estimate PR and determine the factors associated with seroprevalence.

Dogs that consumed untreated water were 0.87 times more likely to be seropositive, i.e., there was an $87 \%$ increase in prevalence. This data warns of possible contamination of the water used by the population, mainly from wells. It should also be noted that pathogenic leptospires have already been found in well water (Astuti et al. 2019) and can survive for long periods in aqueous or semi-solid environments (Trueba et al. 2004).

Dogs whose blood samples were taken in the rainy season were 0.94 more likely to be seroreactive, with a $94 \%$ increase in prevalence. According to data from the "Agência Executiva de Gestão das Águas do Estado da Paraíba" (AESA 2019), the rainfall rate in the rainy season was 2.7 times higher than the dry season. Taking into account that still water and sewage may contain pathogenic leptospires in urban areas (Casanovas-Massana et al. 2018), this increase in the number of seropositive animals may be related to the spread of the agent due to rain. Associated with this, the increase in soil moisture is given as an important risk factor for the occurrence of the disease (Baquero \& Machado 2018), as it favors the maintenance of the bacteria in the environment.

Male dogs were 1.10 times more likely to be seropositive, i.e., there was a $110 \%$ increase in prevalence. This may be related to the male dog reproductive habits, including licking and sniffing the female's genitals, increasing the chances of contact with contaminated urine. In addition, pathogenic leptospires were detected in urine from naturally infected dogs in the Brazil with the serovar Icterohaemorrhagiae (Miotto et al. 2018b).

Dogs with free access to the street were 1.15 times more likely to be seropositive ( $115 \%$ increase in prevalence). This may be related to increased exposure to the agent when compared to domiciled dogs. Among the possible ways of infection, these dogs may have contact with infected animals, mainly with stray dogs that tend to be reservoirs of pathogenic leptospires (Miotto et al. 2018a), or have contact with water contaminated with urine of synanthropic animals, main reservoirs in urban areas (Brasil 2017).

Dogs whose owners reported contact with wildlife were 2.54 more likely to be seropositive, representing a $254 \%$ increase in prevalence. Therefore, it should be noted that the studied area has several fragments of Atlantic Forest close to urban areas, being composed of a great biodiversity of fauna and flora (Porto et al. 2004). It suggests that the potential of its fauna as a carrier of infectious agents has yet to be elucidated, since wildlife can act as remarkable reservoirs of pathogenic leptospires (Vieira et al. 2016, 2019).

Dogs older than five years were 3.21 times more likely to be seropositive (321\% increase in prevalence). This finding was also found in other surveys with dogs (Mascolli et al. 2016, Fernandes et al. 2018a) and may be related to the longer exposure time to the agent when compared to younger animals. 


\section{CONCLUSIONS}

The high real prevalence of Leptospira sp. in a transmission region of the semiarid of Paraíba and the occurrence of seroreactive animals in all the municipalities suggest wide distribution of the infection and reinforce the need for preventive measures to avoid infection in pets and, consequently, to humans.

The analysis of factors associated with the prevalence suggest greater manegment cares with the dogs.

Conflict of interest statement. - The authors have no competing interests.

\section{REFERENCES}

AESA 2019. Meteorologia - Chuvas. Agência Executiva de Gestão das Águas. Available at <http://www.aesa.pb.gov.br/aesa-website/meteorologiachuvas/> Accessed on Apr. 21, 2020.

Allen S.E., Ojkic D. \& Jardine C.M. 2014. Prevalence of antibodies to Leptospira in wild mammals trapped on livestock farms in Ontario, Canada. J. Wildl. Dis. 50(3):666-670. <https://dx.doi.org/10.7589/2013-11-292> <PMid:24807356>

Alves C.J., Alcino J.F., Farias A.E.M., Higino S.S.S., Santos F.A., Azevedo S.S., Costa D.F. \& Santos C.S.A.B. 2012. Epidemiological characterization and risk factors associated with leptospirosis in the Brazilian semiarid. Pesq. Vet. Bras. 32(6):523-528. <https://dx.doi.org/10.1590/S0100-736X2012000600009>

Alves C.J., Clementino I.J., Oliveira A.G.F., Freitas T.D., Vasconcellos S.A. \& Morais Z.M. 2004. Avaliação dos níveis de aglutininas antileptospira em cães de caça na Paraíba, Brasil. Revta Bras. Ciênc. Vet. 11(1/2):68-73. <https://dx.doi.org/10.4322/rbcv.2014.347>

Araújo Neto J.O., Alves C.J., Azevedo S.S., Silva M.L.C.R. \& Batista C.S.A. 2010. Soroprevalência da leptospirose em caprinos da microrregião do Seridó Oriental, Estado do Rio Grande do Norte, Brasil, e pesquisa de fatores de risco. Braz. J. Vet. Res. Anim. Sci. 47(2):150-155.

Astuti N.T., Sakundarno M., Setyaningsih Y., Martini M. \& Saraswati L.D. 2019. The presence of pathogenic Leptospira sp. in water bodies in Klaten District. Indian J. Publ. Health Res. Develop. 10(1):439-443. <https:// dx.doi.org/10.5958/0976-5506.2019.00087.1>

Azevedo S., Fernandes A., Queiroga I., Alves C., Morais Z., Santos C. \& Vasconcellos S. 2011. Occurrence and risk factors associated with leptospirosis in dogs attended in a veterinary hospital in the semiarid of the Paraíba State, Northeast region of Brazil. Braz. J. Vet. Res. Anim. Sci. 48(2):161-166. <https://dx.doi.org/10.11606/S1413-95962011000200009>

Baquero O.S. \& Machado G. 2018. Spatiotemporal dynamics and risk factors for human Leptospirosis in Brazil. Sci. Rep. 8:15170. <https://dx.doi. org/10.1038/s41598-018-33381-3>

Barbante P., Shimabukuro F.H., Langoni H., Richini-Pereira V.B. \& Lucheis S.B. 2014. Leptospira spp. infection in sheep herds in southeast Brazil. J. Venom. Anim. Toxins incl. Trop. Dis. 20:9-15. <https://dx.doi.org/10.1186/16789199-20-20>

Batista C.S.A., Azevedo S.S., Alves C.J., Vasconcellos S.A., Morais Z.M., Clementino I.J., Lima F.L. \& Araújo Neto J.O. 2004. Soroprevalência de leptospirose em cães errantes da cidade de Patos, Estado da Paraíba, Brasil. Braz. J. Vet. Res. Anim. Sci. 41(2):131-136. <https://dx.doi.org/10.1590/S141395962004000200009>

Benacer D., Zain S.N.M., Amran F., Galloway R.L. \& Thong K.L. 2013. Isolation and molecular characterization of Leptospira interrogans and Leptospira borgpetersenii isolates from the urban rat populations of Kuala Lumpur, Malaysia. Am. J. Trop. Med. Hyg. 88(4):704-709. <https://dx.doi.org/10.4269/ ajtmh.12-0662><PMid:23358635>

Brasil 2017. Leptospirose - Guia de Vigilância em Saúde [recurso eletrônico]. $2^{a}$ ed. Ministério da Saúde, Brasília, p.569-588. Available at <http:// portalarquivos.saude.gov.br/images/pdf/2017/outubro/06/VolumeUnico-2017.pdf> Accessed on Jul. 13, 2020.

Brasil A.W.L., Costa D.F., Pimenta C.L.R.M., Parentoni R.N., Alves C.J., Santos C.S.A.B. \& Azevedo S.S. 2018. Prevalence and risk factors to Leptospira sp. infection in dogs attended at veterinary clinics in João Pessoa, Paraíba
State, Northeastern Brazil. Braz. J. Vet. Res. Anim. Sci. 55(3):1-9. e144154 <https://dx.doi.org/10.11606/issn.1678-4456.bjvras.2018.144154>

Casanovas-Massana A., Costa F., Riediger I.N., Cunha M., Oliveira D., Mota D.C., Sousa E., Querino V.A., Nery Jr. N., Reis M.G., Wunder Jr E.A., Diggle P.J. \& Ko A.I. 2018. Spatial and temporal dynamics of pathogenic Leptospira in surface waters from the urban slum environment. Water Res. 130:176-184. <https://dx.doi.org/10.1016/j.watres.2017.11.068><PMid:29220718>

Castro J.R., Salaberry S.R.S., Souza M.A. \& Lima-Ribeiro A.M.C. 2011 Predominant Leptospira spp. serovars in serological diagnosis of canines and humans in the city of Uberlândia, State of Minas Gerais, Brazil. Revta Soc. Bras. Med. Trop. 44(2):217-222. <https://dx.doi.org/10.1590/S003786822011005000012>

Castro J.R., Souza M.A., Cardoso Neto A.B., Moreira R.Q., Salaberry S.R.S., Guimarães E.C. \& Lima A.M.C. 2015. Presence of antibodies against Leptospira spp. in dogs of Uberlandia, MG, Brazil. Biosci. J. 31(4):1183-1188. <https://dx.doi.org/10.14393/BJ-v31n4a2015-26173>

Cumberland P., Everard C.O.R. \& Levett P.N. 1999. Assessment of the efficacy of an IgM-ELISA and microscopic agglutination test (MAT) in the diagnosis of acute leptospirosis. Am. J. Trop. Med. Hyg. 61(5):731-734. <https://dx.doi.org/10.4269/ajtmh.1999.61.731><PMid:10586903>

Dohoo I.R., Martin W. \& Stryhn H. 1996. Veterinary Epidemiologic Research. Atlantic Veterinary College, Charlottetown. 865p.

Ellis WA. 2015. Animal leptospirosis. Curr. Top. Microbiol. Immunol. 387:99-137. <https://dx.doi.org/10.1007/978-3-662-45059-8_6><PMid:25388134>

Fernandes A.R.F., Costa D.F., Andrade M.R., Bezerra C.S., Mota R.A., Alves C.J., Langoni H. \& Azevedo S.S. 2018a. Seropositivity and risk factors for leptospirosis, toxoplasmosis and neosporosis in the canine population of Paraíba state, northeastern Brazil. Pesq. Vet. Bras. 38(5):957-966. <https://dx.doi.org/10.1590/1678-5150-pvb-5137>

Fernandes A.R.F., Costa D.F., Pimenta C.L.R.M., Araújo K.N., Silva R.B.S., Melo M.A., Langoni H., Mota R.A. \& Azevedo S.S. 2018b. Occurrence and risk factors of zoonoses in dogs and owners in Sertão, Paraíba State, Northeastern Brazil. Semina, Ciênc. Agrárias 39(3):1057-1066. <https://dx.doi.org/10.5433/1679-0359.2018v39n3p1057>

Freire I.M.A., Varges R. \& Lilenbaum W. 2008. Hepatic biochemistry alterations in dogs with naturally occurring acute leptospirosis determined by Icterohaemorrhagiae serogroup. Ciência Rural 38(9):2630-2632. <https:// dx.doi.org/10.1590/S0103-84782008005000020>

Freitas J.C., Silva F.G., Oliveira R.C., Delbem A.C.B., Müller E.E., Alves L.A. \& Teles P.S. 2004. Isolation of Leptospira spp. from dogs, bovine and swine naturally infected. Ciência Rural 34(3):853-856. <https://dx.doi org/10.1590/S0103-84782004000300030>

Haake D.A. \& Levett P.N. 2015. Leptospirosis in humans. Curr. Top. Microbiol. Immunol. 387:65-97. <https://dx.doi.org/10.1007/978-3-662-45059-8_5> <PMid:25388133>

Hafemann D.C.M., Merlini L.S., Gonçalves D.D., Fortes M.S., Navarro I.T., Chiderolli R.T., Freitas J.C., Gonçalves A.P.P., Rosa G. \& Sposito P. H. 2018. Detection of anti-Leptospira spp., anti-Brucella spp., and anti-Toxoplasma gondii antibodies in stray dogs. Semina, Ciênc. Agrárias, Londrina, 39(1):167-176. <https://dx.doi.org/10.5433/1679-0359.2018v39n1p167>

Higino S.S.S., Alves C.J., Alves C.J., Santos C.S.A.B., Vasconcellos S.A., Silva M.L.C.R., Brasil A.W.L., Pimenta C.L.R.M.\& Azevedo S.S. 2012. Prevalência de leptospirose em caprinos leiteiros do semiárido paraibano. Pesq. Vet. Bras. 32(3):199-203.<https://dx.doi.org/10.1590/S0100-736X2012000300003>

Higino S.S.S., Azevedo S.S., Alves C.J., Figueiredo S.M., Silva M.L.C.R. \& Batista C.S.A. 2010. Frequência de leptospirose em ovinos abatidos no município de Patos, Paraíba. Arq. Inst. Biológico, São Paulo, 77(3):525-527.<https:// dx.doi.org/10.1590/1808-1657v77p5252010>

Higino S.S.S., Santos F.A., Costa D.F., Santos C.S.A.B., Silva M.L.C.R., Alves C.J. \& Azevedo S.S. 2013. Flock-level risk factors associated with leptospirosis in dairy goats in asemiarid region of Northeastern Brazil. Prev. Vet. Med. 109(1/2):158-161.<https://dx.doi.org/10.1016/j.prevetmed.2012.09.005>

IBGE 2010. Panorama. Instituto Brasileiro de Geografia e Estatística. Available at $<$ https://cidades.ibge.gov.br/brasil/pb/panorama> Accessed on Feb. 23, 2020 
Lane A.B. \& Dore M.M. 2016. Leptospirosis: a clinical review of evidence based diagnosis, treatment and prevention. World J. Clin. Infect. Dis. 6(4):61-66. <https://dx.doi.org/10.5495/wjcid.v6.i4.61>

Lemos J.P., Melo C.B. \& Viegas S.A.R.A. 2010. Análise sorológica de Leptospira spp. em cães errantes no município de Aracaju. Revta Cient. Eletrôn. Med. Vet. 8(14):1-16.

Martinez B.A.F., Leotti V.B., Silva G.S., Nunes L.N., Machado G. \& Corbellini L.G. 2017. Odds ratio or prevalence ratio? An overview of reported statistica methods and appropriateness of interpretations in cross-sectional studies with dichotomous outcomes in veterinary medicine. Front. Vet. Sci. 4:193. <https://dx.doi.org/10.3389/fvets.2017.00193> <PMid:29177157>

Mascolli R., Soto F.R.M., Bernardi F., Ito F.H., Pinheiro S.R., Guilloux A.G.A., Azevedo S.S., Fernandes A.R.F., Keid L.B., Morais Z.M., Souza G.O. \& Vasconcellos S.A. 2016. Prevalence and risk factors for leptospirosis and brucellosis in the canine population of the Tourist Resort of Ibiúna, State of São Paulo, Brazil. Arq. Inst. Biológico, São Paulo, 83:1-7. e0842014. <https://dx.doi org/10.1590/1808-1657000842014>

Miotto B.A., Guilloux A.G.A., Tozzi B.F., Moreno L.Z., Hora A.S., Dias R.A., Heinemann M.B., Moreno A.M., Souza Filho A.F., Lilenbaum W. \& Hagiwara M.K. 2018a. Prospective study of canine leptospirosis in shelter and stray dog populations: identification of chronic carriers and different Leptospira species infecting dogs. PLoS One 13(7):e0200384. <<https://dx.doi. org/10.1371/journal.pone.0200384> <PMid:29995963>

Miotto B.A., Tozzi B.F., Penteado M.S., Guilloux A.G.A., Moreno L.Z., Heinemann M.B., Moreno A.M., Lilenbaum W. \& Hagiwara M.K. 2018b. Diagnosis of acute canine leptospirosis using multiple laboratory tests and characterization of the isolated strains. BMC Vet. Res. 14:222.<https://dx.doi.org/10.1186/ s12917-018-1547-4>

Miraglia F., Moreno L.Z., Morais Z.M., Langoni H., Shimabukuro F.H., Dellagostin O.A., Hartskeerl R., Vasconcellos S.A. \& Moreno A.M. 2015. Characterization of Leptospira interrogans serovar Pomona isolated from swine in Brazil. J. Infect Develop. Ctries 9(10):1054-1061. <https://dx.doi.org/10.3855/jidc.5507> $<$ PMid:26517479>

Morikawa V.M., Bier D., Pellizzaro M., Ullmann L.S., Paploski I.A.D., Kikuti M., Langoni H., Biondo A.W. \& Molento M.B. 2015. Seroprevalence and seroincidence of Leptospira infection in dogs during a one-year period in an endemic urban area in Southern Brazil. Revta Soc. Bras. Med. Trop. 48(1):50-55. <https://dx.doi.org/10.1590/0037-8682-0213-2014>

Noordhuizen J.P.T.M., Frankena K., Van Der Hoofd C.M. \& Graaf E.A.M. 1997 Application of Quantitative Methods in Veterinary Epidemiology. Wageningen Pers, Wageningen. 429p.

OIE 2018. Leptospirosis: terrestrial manual. World Organisation for Animal Health, p.503-516. Available at <https://www.oie.int/fileadmin/Home/eng/ Health_standards/tahm/3.01.12_LEPTO.pdf> Accessed on Apr. 21, 2020

OIE 2019. One Health "at a glance". World Organisation for Animal Health. Available at <https://www.oie.int/en/for-the-media/onehealth/> Accessed on Apr. 21, 2020

Oliveira L.A., Zaniolo M.M., Dias E.H., Brandão H.B.S., Rubio K.A.J., Ferreira B.P.M., Nakamura A.Y., Chideroli R.T., Freitas J.C. \& Gonçalves D.D. 2016. Leptospirosis and brucellosis seroepidemiology in sheep and dogs from non-mechanized rural properties in the northwestern region in the state of Paraná. Semina, Ciênc. Agrárias 37(5):3147-3158. <https://dx.doi. org/10.5433/1679-0359.2016v37n5p3147>

Oliveira S.T., Messick J.B., Biondo A.W., Santos A.P., Stedile R., Dalmolin M.L., Guimarães A.M.S., Mohamed A.S., Riediger I.N. \& González F.H.D. 2012 Exposure to Leptospira spp. in sick dogs, shelter dogs and dogs from an endemic area: points to consider. Acta Scient. Vet. 40(3):1056.

Paz G.S., Rocha K.S., Lima M.S., Jorge E.M., Pantoja J.C.F., Moraes C.C.G. \& Langoni H. 2015. Seroprevalence for brucellosis and leptospirosis in dogs from Belém and Castanhal, State of Pará, Brazil. Acta Amazonica 45(3):265-270. <https://dx.doi.org/10.1590/1809-4392201403486>

Pedersen K., Anderson T.D., Maison R.M., Wiscomb G.W., Pipas M.J., Sinnett D.R., Baroch J.A. \& Gidlewski T. 2018. Leptospira antibodies detected in wildlife in the USA and the US virgin islands. J. Wildl. Dis. 54(3):450-459. <https://dx.doi.org/10.7589/2017-10-269><PMid:29715063>

Pimenta C.L.R.M., Bezerra C.S., Morais D.A., Silva M.L.C.R., Nogueira D.B., Costa D.F., Santos C.S.A.B., Higino S.S.S., Alves J.C. \& Azevedo S.S. 2019. Seroprevalence and predominant serogroups of Leptospira sp. in serological tests of ruminants in northeastern Brazil. Semina, Ciênc. Agrárias 40(4):1513-1522. <https://dx.doi.org/10.5433/1679-0359.2019v40n4p1513>

Pinto-Ferreira F., Pasquali A.K.S., Thomaz-Soccol V., Mitsuka-Breganó R., Caldart E.T., Leandro A.S., Chiyo L., Pozzolo E.M., Cubas P., Giordano L.G.P., Petterle R.R. \& Navarro I.T. 2019. Epidemiological relevance of dogs for the prevention of Toxoplasma gondii, Neospora caninum and Leptospira spp. Braz. J. Vet. Parasitol. 28(3):383-394. <https://dx.doi.org/10.1590/ s1984-29612019043>

Porto K.C., Cabral J.J.P. \& Tabarelli M. 2004. Brejos de altitude em Pernambuco e Paraíba: história natural, ecologia e conservação. Ministério do Meio Ambiente, Brasília. Available at <http://www.terrabrasilis.org.br/ ecotecadigital/pdf/brejos-de-altitude-em-pernambuco-e-paraiba-.pdf> Accessed on Apr. 21, 2020.

Romero E.C., Bernardo C.C.M. \& Yasuda P.H. 2003. Human leptospirosis: a twenty-nine-year serological study in São Paulo, Brazil. Revta Inst. Med. Trop. S. Paulo 45(5):245-248. <https://dx.doi.org/10.1590/S0036$46652003000500002>$

Scialfa E., Bolpe J., Bardón J.C., Ridao G., Gentile J. \& Gallicchio O. 2010. Isolation of Leptospira interrogans from suburban rats in Tandil, Buenos Aires, Argentina. Revta Argent. Microbiol. 42(2):126-128. <https://dx.doi. org/10.1590/S0325-75412010000200012> <PMid:20589335>

Silva E.R.D.F.S., Castro V., Prianti M.G., Gonçalves L.M.F., Sobrinho Jr E.P.C., Drumond K.O. \& Mineiro A.L.B.B. 2017a. Occurrence of antibodies against Leptospira spp. in dogs from Teresina, Piauí, Brazil. Braz. J. Vet. Res. Anim. Sci. 54(1):8891. <https://dx.doi.org/10.11606/issn.1678-4456.bjvras.2017.110588>

Silva J.D., Alves J.R.A., Costa D.F., Correia E.L.B., Melo D.H.M., Higino S.S.S., Azevedo S.S. \& Alves C.J. 2017b. Epidemiological characterization and risk factors associated with Leptospira infection in dogs from rural settlements in the semi-arid region of Northeast Brazil. Semina, Ciênc. Agrárias 38(4 Supl.1):2531-2541. <https://dx.doi.org/10.5433/16790359.2017v38n4Supl1p2531>

SINAN 2017. Dados Epidemiológicos Sinan: doenças e agravos de notificação - de 2007 em diante. Sistema de Informação de Agravos de Notificação. Available at <http://portalsinan.saude.gov.br/dados-epidemiologicossinan> Accessed on Apr. 21, 2020.

Thrusfield M. 2007. Veterinary Epidemiology. Wiley Blackwell, Oxford. 610p.

Trueba G., Zapata S., Madrid K., Cullen P. \& Haake D. 2004. Cell aggregation: a mechanism of pathogenic Leptospira to survive in fresh water. Int. Microbiol. 7(1):35-40. <PMid:15179605>

Vieira A.S., Azevedo M.I.N., D’Andrea P.S., Vilela R.V. \& Lilenbaum W. 2019. Neotropical wild rodents Akodon and Oligoryzomys (Cricetidae: Sigmodontinae) as important carriers of pathogenic renal Leptospira in the Atlantic forest, in Brazil. Res. Vet. Sci. 124:280-283. <https://dx.doi. org/10.1016/j.rvsc.2019.04.001> <PMid:31004919>

Vieira A.S., Narduche L., Martins G., Péres I.A.H.F., Zimmermann N.P., Juliano R.S. Pellegrin A.O. \&_Lilenbaum W. 2016. Detection of wild animals as carriers of Leptospira by PCR in the Pantanal biome, Brazil. Acta Trop. 163:87-89. <https://dx.doi.org/10.1016/j.actatropica.2016.08.001><PMid:7496621>

Zar J.H. 1999. Biostatistical Analysis. 4th ed. Prentice-Hall, New Jersey. 929p.

Zarantonelli L., Suanes A., Meny P., Buroni F., Nieves C., Salaberry X., Briano C., Ashfield N., Silveira C.S., Dutra F., Easton C., Fraga M., Giannitti F., Hamond C., Macías-Rioseco M., Menéndez C., Mortola A., Picardeau M., Quintero J., Cristina Ríos C., Rodríguez V., Romero A., Varela G., Rivero R., Schelotto F., Riet-Correa F. \& Buschiazzo A. 2018. Isolation of pathogenic Leptospira strains from naturally infected cattle in Uruguay reveals high serovar diversity, and uncovers a relevant risk for human leptospirosis. PLoS Negl. Trop. Dis. 12(9):e0006694. <https://dx.doi.org/10.1371/journal. pntd.0006694> <PMid:30212451> 